\title{
Rulers against Writers, Writers against Rulers: The Failed Promise of the Public Sphere in Postcolonial Nigerian Fiction
}

\author{
Ayo Kehinde*
}

\begin{abstract}
Various literary critics have dwelt on the nature, tenets and trends of commitment in Nigeria literature. However, there is paucity of scholarly studies on the representations of the failed promise to the public sphere in postcolonial Nigerian fiction. This paper, therefore, examines the strategies and technicalities of representing the castrated hope of the public sphere in postcolonial Nigerian fiction, using the templates provided by Chinua Achebe's Anthills of the Savannah, Ben Okri's The Famished Road and Chimamanda Ngozi Adichie's Purple Hibiscus. The methodology involves a close reading of the selected texts, using Jürgen Habermas's concept of the Public Sphere as the theoretical framework. The paper reveals that the context of the texts (Nigeria) lacks the public sphere, which is supposed to provide a liminal space between the private realm of civil society and the family, as well as the sphere of public authority. This is disclosed in the refusal of the characters to disregard 'status altogether' (Habermas 1991:36).
\end{abstract}

\section{Résumé}

Plusieurs critiques littéraires ont insisté sur la nature, les principes et les tendances de l'engagement dans la littérature nigériane. Cependant, il existe peu d'études scientifiques sur les représentations de la promesse manquée de la sphère publique dans la littérature postcoloniale nigériane. Ainsi, le présent article examine les stratégies et les techniques de représentation de l'espoir castré de la sphère publique dans la littérature postcoloniale nigériane, en utilisant les modèles fournis par Anthills of the Savannah de Chinua Achebe, The Famished Road de Ben Okri et Purple Hibiscus de Chimamanda Ngozi Adichie. La méthodologie implique une lecture attentive des textes sélectionnés, en utilisant le

* Department of English, University of Ibadan, Nigeria.

E-Mail: ayobamikehinde2000@yahoo.com; ma.kehinde@mail.ui.edu.ng 
concept de sphère publique de Jürgen Habermas comme cadre théorique. L'article révèle que le contexte des textes (le Nigeria) est dépourvu de sphère publique, qui est censée offrir un espace liminal entre le domaine privé de la société civile et de la famille, ainsi que la sphère de l'autorité publique. Ceci est indiqué dans le refus des personnages de méconnaitre « complètement le statut » (Habermas 1991:36).

\section{Introduction}

The term, 'Public Sphere', most especially from the perspective of literature, is notoriously a slippery concept, designating, as it does, a form of art, a spirit, a purpose and a tone. For many years, much thought on this topic has been influenced by Jürgen Habermas, who proposed that, in eighteenthcentury England, middle-class citizens began to see themselves as effective members of a rational public. Communicating ever more volubly in café society, literary clubs and the press, more and more British subjects could see it as their proper role to debate and pass judgements on matters they deemed important to the collective life of the nation. This set of communicative institutions and behaviours Habermas designates 'the bourgeois public sphere'. Nancy Fraser (1992) argues that the public sphere is a 'conceptual resource designating a theatre in modern societies in which political participation is enacted through the medium of talk. It is the space in which citizens deliberate about their common affairs, and hence an institutionalized arena of discursive interaction' (1992:110). Thus, the public sphere as a concept refers to an ideal of unrestricted rational discussion of public matters, a utopian space where interlocutors set aside characteristics such as difference in birth and fortune and speak to one another as if they were social and economic peers. However, gender, sex, race, ethnicity, social classes, and the like have always impeded the actualization of the public sphere. Therefore, this mode of communicative rationality was in subsequent centuries displaced by the logic of consumer capitalism (Habermas's real target), and it is indeed debatable whether any people at the time really imagined themselves taking part in the pure exchange of ideas.

The primary tenet of the ideal public sphere, as conceived by Habermas, is similar to the experience of Nigerian masses who were always involved, at least indirectly, during the pre-colonial era, in the gathering of public opinions on politics, commerce, entertainment, the arts, ecology and religion. For instance, among the Yoruba of Nigeria in the past, the calabash would be opened for a bad king whose rule was threatening the life of the community. This is an 'àrokò' (sign communication), telling him to vacate the throne through an act of suicide. At Onitsha, in Anambra State of Nigeria, a king 
whose reign threatened the life of the community would be asked to vacate the throne and commit suicide by ritual death through the occupation of the throne by a royal masquerade. This signifies a condition of equality among speakers and listeners, not necessarily in wealth or social influence, but in the ability to speak and be heard. In the public sphere, people become important because other people find their actions or attributes worth talking about. A public figure can become so only by the rational affirmation of many citizens speaking to one another. According to Brian Glover (2004), 'to be public is to do something that the public will recognize and acclaim' (2004:10). This is also the case of fictional heroes in prose fiction whose virtues make them admirable.

However, Habermas himself points out, in a brief aside on Goethe's Wilhelm Meister's Apprenticeship, that this idea of the public sphere does not always sit well with the people it supposedly benefits. Rather, most of them go for the Monarchs' 'Publicness' in which the latter are understood as superior beings and as allegorical figures representing something greater than their individual persons. They scarcely try to enter discussions or appeal to the judgement of the ruled. In fact, they reject the contest of ideas, thereby behaving like anti-heroes or antagonists in prose fiction.

It is against the foregoing background that this paper examines the troubles that Nigerian writers face in carrying out the task of exposing their rulers' efforts to alienate the governed from the public sphere. It also investigates and critiques three fictional case studies of how neo-colonial Nigerian rulers exclude some citizens from the utopian space of the public sphere in the country. It is argued that Achebe's Anthills of the Savannah, Ben Okri's The Famished Road and Chimamanda Adichie's Purple Hibiscus yield singular insight and provocation to a theoretical understanding of the concept of the Public Sphere. It is also argued that Nigerian postcolonial fiction affords an indispensable medium for teasing out and exploring the fraught, antithetical meanings embedded within the notion of the Public Sphere, that is, human rights. By revealing the fairness of the contemporary regime of the Public Sphere in the nation, postcolonial Nigerian fiction paradoxically suggests a location for a re-conceptualization of a newly invigorated, capacious and robust vision of social justice in the nation.

\section{The Sword and the Pen: An Enduring Dissonant Relationship}

Knowledge is developing, and the divisions that existed among different disciplines are being erased. This informs the incursion of literature into the fields of social sciences and Human Communication. Thus, the rapprochement between African fiction and Habermas's theory of the public sphere is not an anathema. Writers are useful as watchdogs in societies, as they help 
protect the public from those who do harm - from high government officials to petty criminals. They help to shape public thoughts, spark debates and fight for societal good and against societal ills. They embolden the masses and give them hope when it seems there is none. Writers may be too critical and too adversarial or become like mere lapdogs, too timid to take on the sometimes dangerous, often tedious and costly task. Over the years, politics and socio-historical realities have exerted a pull on Nigerian writers. However, writers' endeavours to expose and critique the misdeeds of rulers have always been continually challenged.

The ancient belief that the poet (the writer) has magical powers still survives in certain distorted ways today. In early European culture, the writer was associated with awful audacity. He had the ability to encroach on divine prerogative, akin to the belief among the Yoruba that the king dares not kill a writer (Oba kì í pa òkorin). In traditional Yoruba society, the writer was a protected being, even for a king. Therefore, he was an object of peoples' admiration, a target of their ambivalence, dogged, and heroically prepared to die in defence of the ancient right of the poets. He stood in a very special relation to his society by enhancing its well-being, defending it from its enemies, and mediating between the governed and the rulers. However, all these virtues, rights and obligations of a writer came with a complementary danger, both personal and social. A writer was an object of hate and fear, both honoured and loved for his or her positive roles. The writer was hated and feared because of this power to expose ills. Such was and is the ambivalent attitude of society toward its writers. The ancient law, most especially The Roman Twelve Tables, threatened with death anyone who would 'chant an evil charm'. Plato's laws also recommended extremely severe penalties against similar activities. Old Irish law undertook, zealously, to regulate the activities of writers, making provision for the reward of 'good' writing (directed toward a socially sanctioned end), but laying down heavy penalties for 'bad' writing (that which was wantonly injurious). Writers were then banned for libels, and skated on the thin edge of censorship and legal retribution.

The writer faces comparable problems today. In democratic countries, like Nigeria, the writer attacks individuals only at the risk of grave financial loss to himself and his publisher or risks death during the reign of a totalitarian ruler. In fact, there are considerable demonstrable effects of political and economic pressures on Nigerian writers in the form of restrictions and repression. In Nigeria, like in many other countries of the world, freedom of expression in general and for the press or for writers is the exception rather than the rule. Some writers in the country have been subjected to imprisonment, and some have been gruesomely murdered. There is a seeming 
cold war between the sword (the ruler) and the pen (the writer) in Nigeria. Freedom House rates Nigeria's news media as 'partly free', with 53 points on a scale of zero to a hundred. With respect to this rating, one should note that Nigeria's constitution ostensibly guarantees freedom of expression and of the press. However, it is observed that the state often uses arbitrary action and extra-legal measures to suppress political criticism and expression in the media and creative writings. It can also be noted that libel remains a criminal offence and the burden of proof in such cases rests with the defendant. Nigeria's State Security Services are known to use arbitrary detention and extra-judicial measures in attempts to suppress expressions of the press and writers, and to muffle political activism and criticism.

One pertinent issue which should be resolved at this juncture is this: Do Nigerian writers attack institutions or the perversions of institutions? To Northrop Frye, the writer attacks primarily neither the man nor the institution; he only attacks an evil man who is given high stature and protected by the prestige of the institution. In Frye's words, 'the cowl might make the monk if it were not for the satirist' (1945:80). However, rulers frequently react violently against writers' attacks, because it could be argued that such attacks lead to an indefinite extension in the reader's mind, and thus into an assault on the whole structure of that which the phenomenon is part. What primarily stands as a local attack often ends by calling the whole institution into question. Therefore, the ruler will keep on suspecting the writer, and the relationship of a writer to society will necessarily remain problematic. A very recent example of the dissonant relationship between the ruler and the writer in Nigeria was the conflict between the writers in Kano State and the Censors Board constituted and inaugurated by the government of the state. In his defence of the attempt of the government to censor all publications in the state, Abubakar Rabo, the Director General, asserted:

Knowing how important reading is to the development of the mind, it is very essential that we safeguard what the public is reading, especially our youths. There are some literatures that are obscene going around, such are the types we are trying to kick against (The Nation, 6 August 2008:26).

However, some writers see the Censors Board as outrageous and anachronistic. For instance, Denja Abdullahi, the national secretary of the Association of Nigerian Authors (ANA), reacted to the setting up of the Board as follows:

The action is condemnable. It is like taking us back to the Stone Age. Banning of literature in a society sets it back to the time of the Stone Age. It is not good for the country and the society at large. There is no need for that. Presently, there is no place in the world where such is done (The Nation, 6 August 2008:27). 
Niyi Osundare frankly decries the existence of the Board:

Censors board? What does Censors board have to do with writing? It is backward and extensively diversionary. This is grotesquery. I thought we have left this behind hundreds of years ago. At a time when the whole world is moving forward, Nigeria appears to be backward, and with this development, then, it shows that we are actually retrogressing very fast. This takes us back to 1644 when John Milton the great English poet wrote Areopagitica. He did it in respect of free speech and unhampered expression (The Nation, 6 August 2008:27).

Thus, it is an open secret that there is an uneasy relationship between the rulers and the writers in Nigeria. Governments have imposed varying levels of censorship on the writers. Even when not censored, their works may be subject to intense scrutiny. At one extreme, Nigerian writers have been called propagandists, labelled unpatriotic, even treasonous. However, it should be reiterated that freedom of writers and the press is a cornerstone of democracy. People have a need to know, and writers have a right to tell. However, responsibility includes the duty to be fair. Nigeria has experienced a turbulent social and political history, and there is an alarming climate of political, social and economic tension in the country.

\section{Fictional Case Studies of the Failed Promise of the Public Sphere in Nigeria}

Despite the official pressure and even violence directed against them, Nigerian writers are still vibrant and are especially vocal about unpopular state policies. They are always a source of inspiration and consolation through their works during the reign of despots who enact poison-tipped policies, ruling the nation with rod and scorpion. In such periods, nothing moves as it is supposed to; only official corruption, official killing, do-or-die politics and the like thrive unabated. Nigerian writers always rise to the occasion and challenge the excesses of government that are detrimental to the well-being of the nation. Of course, it is difficult to determine the precise influence of Nigerian writers in trying to sustain the evolving democracy. But one wonders what the nation would have become at the hands of the neo-colonial rulers of the country if Nigerian writers had put down their pens. Adebayo Williams contends that:

African writers have resisted oppression and injustice on the continent with great force and courage. Literature is fundamentally incompatible with tyranny. In its purest state, literature is subversive of authority and authoritarian rulers. Its joyous and spontaneous celebration of life, its near anarchic contempt for regulation and regimentation makes it the most natural enemy of dictatorship. While the dictator seeks a total domination of men and society, literature often seeks their total liberation (1996:350). 
Creative and critical literature in Nigeria is more than ever before required. It is no longer a question of how the British colonialists 'ruined' the country, but of how Nigerian leaders have aborted the great hopes and expectations of independence. As the comment by Niyi Osundare cited above argues, socio-political commitment is not a mere aside, a parenthesis or a footnote in the creative consciousness of postcolonial Nigerian writers. They write not only to entertain and please, but to change their society in the process.

Chinua Achebe's 'Anthills of the Savannah': An Imaginative Chronicle of 'The Trouble with Nigeria's Public Sphere'

In his essays and interviews, Achebe maintains that in Africa, literature is a communal celebration. Thus, the African writer has no choice but to be committed, for there is no room for art for art's sake; rather there is always art for life's sake. In his work, Achebe traces the trouble with Nigeria to the doorstep of tribalism, the absence of patriotism, social injustice, indiscipline, corruption, and the like. These vices, Achebe believes, originate at the top of the political order and work their way down, as we find in his 1984 work, The Trouble with Nigeria.

Following the template offered by Abdul JanMohamed in his analysis of Achebe's writing in the light of Georg Lukacs's theory of realism, this paper analyses the main characters in Anthills of the Savannah and their profound alienation. In this novel, Achebe employs three main characters (Ikem Osodi, the Editor of the National Gazette; Beatrice Okoh, Senior Assistant Secretary, Ministry of Finance; and Chris Oriko, the Commissioner for Information) who in turn narrate the story. With this narrative structure, the reader is enabled to see 'His Excellency' (Sam) and understand the problem of the failed promise of the public sphere in Nigeria from a multi-dimensional perspective.

Anthills of the Savannah is Achebe's most sustained treatment of political issues in post-independence Nigeria. The president of a fictional African state, Kangan (unmistakably Nigeria), is intoxicated with power. In his book The Trouble with Nigeria, Achebe affirms that the trouble with the country is 'simply and squarely a failure of leadership' (1984:1); Anthills of the Savannah is the fictional exposition of this source of failure. In the text, there is a transition from love and friendship to disillusionment and violence. The President is apathetic towards dialogue, constructive criticism, egalitarianism and communication. The public sphere is rejected in his domain, because it is seen as an anathema.

In the world of the novel, the public sphere is not allowed to materialize. The expected avenue "made up of private people gathered together as a public and articulating the needs of society with the state' (Habermas 1991:176) is not allowed to function in the cosmos of Achebe's Anthills of the Savannah. 
Rather, flattery comes to assume the place of real debate, and the moral force of governing is displaced by internal struggles over power. For instance, one of the narrators believes that, in order not to irk the president, it is good to 'keep your mouth shut' (Achebe 1987:2). The Head of State even says authoritatively: 'You know I've never relied on you fellows for information on anything or anybody' (1987:15). He informs the Commissioner for Justice and Attorney-General: 'You may be the Attorney, but don't forget I am the General' (1987:24). Surprisingly, the Attorney-General also concurs by saying: 'we have no problem worshipping a man like you' (1987:24). This reverence is due to His Excellency's personal background. The Attorney-General attended a 'bush grammar school', unlike His Excellency who was born with silver spoon in his mouth and attended an elite school. In fact, within two years of holding the reins of government, Sam has become a totalitarian dictator. The government is absolute in power; it 'holds the yam and holds the knife' (1987:33). Beatrice testifies to the sudden negative metamorphosis of the president:

In the early days of his coming to power I had gone fairly often to the Palace with Chris and sometimes Chris and Ikem. But then things had changed quite dramatically after about a year and now apart from viewing him virtually every night on television news I had not actually set eyes on him nor had any kind of direct contact for well over a year (1987:71).

The President recedes up the hill, communes with his cronies and forgets the very people who legitimize his authority. This is to attest to the fact that many postcolonial African leaders forget that, in Africa everything is connected, interrelated and dependent. Instead, they engage in massive corruption, subservience to foreign manipulation, second-class hand-me-down capitalism, shootings of striking workers and demonstrating students, and destruction and the banning of independent unions and cooperatives. Consequently, there are many fugitives in the fictional nation of Kangan; for instance, Emmanuel Obete, a former President of the Students Union. These problems are attributed to the failure or neglect of the public sphere in the nation, that is: 'the failure of our rulers to re-establish vital inner links with the poor and dispossessed of this country, with the bruised heart that throbs painfully at the core of the nation's being' (1987:141).

The leadership style of His Excellency, Sam, shows that the military operates through 'might is right', and it is usually tyrannical in approach. In fact, the ordeals of the people of Kangan reveal that military rulers are really dictators under whom the masses suffer untold economic and psychological hardships. And for the simple reason that man desires comfort, he rebels 
against oppressive tendencies in the rulers. Crawford Young (2004) comments on this claim thus:

Military intervention became the sole mechanism to displace incumbents, but the putschist in power normally formed a new single party to legitimize permanent status for his rule. Thus citizens became once again merely subjects, facing an exclusion from the public domain reminiscent of colonial times. One important difference: whereas the colonial state asked only obedience, the post-colonial polity demanded affection. Mere submission did not suffice; active participation in rituals, loyally (support marches, assemblies to applaud touring dignitaries, purchase of Party cards, display of the presidential portrait, participation in plebiscitary elections) were mandatory (2004:25).

Because the people become terrified under dictatorship, just a few courageous members of the society take it upon themselves to bear the burden of all and sundry. These individuals become martyrs and heroes in the process. It is the attempt by a few courageous individuals to create alternative voices through which the masses can be informed of developments in their society that gives rise to the resistance culture which runs through Achebe's Anthills of the Savannah.

It becomes extremely difficult for the press to write and publish what it knows to be true. The way the press ignores warning signals, the brutality that befalls the masses of the nation, would have served as a cruel reminder of an intolerant regime that permits and promotes falsehood above national ethics and moral ethos. It is instructive to note that oppressive and repressive regimes prevent freedom of speech to their personal advantage. Since words alone cannot sufficiently bring down a tyrant, there is, therefore, the need for collaboration between the press and members of the pro-democracy pressure groups to create a bigger platform by which the tyrant is confronted and hunted down eventually. Therefore, Sam's attitude to opposition, especially critical views by the press, makes Ikem and his collaborators (Beatrice, activists, labour leaders, and the like) think into existence alternative routes of resisting the draconian rule of military dictatorship. To Ikem, journalism is not meant to make things cosy for leaders who are despotic. It is meant to prod them to act in the interest of the larger society and to cause them sleepless nights (Kunle Ajibade 2003). The press is one organised group that has helped to give bite to the cause of human struggle and resistance against oppression and oppressors in the nation of Kangan. This is a commendable action because, if the press abdicates this responsibility, the leaders will operate without restraints. 
According to Umelo Ojinmah (1991), 'such concepts as moral principles, tolerance for opposition, and the use of power for the benefit of the people do not have much meaning to the leaders' (Ojinmah 1991:61). Sam begins to demonstrate his despotism at a cabinet meeting when he obstinately refuses to visit the drought-stricken province of Abazon. He wants no opposition, and, at all cost, demands the submission of a dissident province to the central authority. He addresses and harasses his cabinet without caring whose ox is gored. His high-handedness is reflected in his abusive words to Chris, the Commissioner for Information: 'I will not go to Abazon. Finish! Kabisa!' (Achebe 1987:1). This rejection of assembly and dialogue unveils the stark reality that military dictators habitually distance themselves from the people they rule. Sam orders Professor Okong, the Commissioner for Home Affairs, to meet the Abazon delegates and give them empty promises about the welfare of the dispossessed and forgotten inhabitants of the province. He urges the Commissioner to 'find some nice words to them. Tell them we are tied up ... with very important matters of the State ... tell them they can be rest assured that their complaints or rather problem ... will receive His Excellency's personal attention' (1987:17). So Sam, in his anti-public-sphere posture, rejects the opportunity of generating opinions and attitudes which could have served to affirm or challenge, therefore, guide the affairs of the nation. Consequently, there is no ideal public sphere in Kangan, due to the anti-democratic temper of the Head of State, who refuses to allow the public opinion needed to 'legitimate authority in any functioning democracy' ( Paul Rutherford 2000:18).

Thus, the abuse of human rights is an endemic problem engulfing the fictional State of Kangan. It is correct, thus, to agree with Ojinmah's (1991) assertion that:

Achebe sees the soldiers as not being any better than the civilians they ousted ... they have become worse, having perfected torture, intimidation and cold-blooded killing as weapons to cow the opponents of their policies (Ojinmah 1991:86).

In his bid to undermine press freedom, Sam charges Chris to check the editorial 'excesses' of Ikem, the Editor of the state-owned newspaper, The National Gazette, so that the naked truth of the president's dictatorship remains concealed. Cases of arbitrary arrest which are replete in Kangan also corroborate the satanic inclination of the military tyrants to unleash the reign of terror on dissidents, as demonstrations, whether peaceful or violent, become a taboo. Six Abazon leaders are maimed because of their alleged complicity in staging a protest against the military despots. The omniscient narrator explains: 'Six leaders from Abazon who were involved in a recent illegal 
march on the Presidential Palace without police permit as required by decree had been arrested' (Achebe 1987:150).

But the educated elite living in the capital city, as exemplified by Chris, Ikem and Beatrice, believe in the creation of the nation-state. They reject the distinction between State and nation, as practised by Sam, the Head of State, and the people of Abazon. The elite, due to their respect for the public sphere, believe in identifying a State and a national atmosphere where the ruler must come from among the people of the nation, identify with them, and the people in turn would identify with the State. However, Sam's regime, because of its hostility towards the Habermasian Public Sphere, does not allow the masses to have a stake in the country. The governing elite is isolated from the masses, symbolized by the air conditioning in the Council Chamber. This literally cuts off the noise of the people protesting outside, thereby depriving the elite of a vital source of knowledge in the everyday experience of the people. Sam turns his cabinet into a group of timorous courtiers and hedonists, who only strive for personal survival and advancement. No critical debates essential for informed process of policy-making exist in the cabinet.

Ikem, a seasoned journalist, is expected to proclaim and protect the President's image by disseminating only what he tells him. On the contrary, Ikem holds tenaciously to the freedom of the press. Achebe seems to rely on the courageous and principled stance that some members of the elite take to envision a nation where the yearning of the masses for the public sphere is met. Ikem, for instance, attempts to provide genuine independent political opinions. However, he is soon labelled as subversive and, subsequently, murdered by the security police. He traces the trouble of the nation to 'the failure of our rulers to establish vital links with the poor and disposed of his country, with the bruised heart that throbs painfully at the core of the nation's being' (1987:141). Sam is killed in a coup, and his tragic flaw is depicted to be his inability to embrace the establishment of a nation-state. He encourages the potentially disastrous discrepancy between the state and the nation. To Habermas, the existence of a distinct public sphere mainly rests upon access to full information being guaranteed to all citizens, not just only small, selfselecting and more or less privileged particular public as the case is in Sam's Kangan. Also, the key idea of attaining truth through unrestricted public discussion among knowledgeable citizens is not allowed by the despot. Through the misrule of Sam, Achebe has, therefore, taken the wrapping off the military government and laid bare its perfidies.

Incompatibility of social classes leads to inevitability of conflicts and struggles. The society is in total grip of the 'petty bourgeoisie', that is, the intelligentsia. The oppressed and deprived people (the workers and peasants) 
are not given major roles to play in the society. According to Emmanuel Ngara, they are 'either pushed to periphery or relegated to oblivion' (Ngara 1990:122). There is a huge gap between the hybrid class of intellectuals and the downtrodden class of the oppressed. This rape of democracy, that is the failure of the public sphere, leads to crisis in the fictional society. There are agitations for free debates against the encroachment of totalitarian control of the military despot and his collaborators, popular protests and later a coup d'état. Since Sam refuses to engage in discourse in the public sphere, that is, he refuses to engage in dialogue with the Abazon delegates, Ikem persists in believing that he can, through his Editorials in The National Gazette, make the President realize that despotism is an abomination in a supposedly democratic state. This is achieved through the efforts of Chris, Ikem and Beatrice to re-establish bonds with the people (shops saleswomen, taxi drivers, student activists, trade unionists, village elders, and the like). Through this effort, they are able to forge at least a brief period of national solidarity and truly representative political consciousness.

Commendably, the hybrid classes of intellectuals - Chris, Ikem and Beatrice as representatives - assume the temper of dynamic characters and take on the responsibility of playing a redemptive role in the society. Kangan workers and peasants are depicted as a social class with enormous potential. This unity-in-diversity shakes the rule of His Excellency and frightens him. The masses of Kangan prove that they are unwilling to remain oppressed, but would rather choose to fight consciously against the lies, corruption and despotism of the ruling class. However, their revolutionary ardour is constrained by their lack of power. This is captured in the allegory of the battle between the Tortoise and the Leopard. Therefore, although the masses come to fight, they do not have any extravagant hope of winning; they only fight symbolically to gain some psychological satisfaction. This is why they need the intellectual guidance and inspiration of the hybrid class. However, the hybrid class, in its attempt to play redemptive role in the society, faces two hurdles. In the first instance, the members of this class must abandon their position as part of the ruling class. Secondly, they need to immerse themselves in the mass of ordinary people, that is, identify themselves with the people and become part of them. They must in effect cross two class borders.

The heroic deaths of Chris and Ikem educate the masses of Kangan and enable them to become aware that reconciliation among various social classes is essential for the unity of the nation. Achebe's prescription for the failed promise of the public sphere in the country is reconciliation among various social classes. They should re-adjust and improve human relationships for 
the sake of the stability of the nation. The rulers should also humble themselves in order to truly understand and care about the people in the downtrodden class. The governed also need to make compromises while fighting to survive. This is revealed, for instance, in the cross-class love between Ikem and Elewa, cross-class understanding between Beatrice and Agatha, and especially in the new born baby, Amaechiwa ('May-the-path-never-end').

\section{Ben Okri's 'The Famished Road': A Magical Refraction of the Failed} Promise of the Public Sphere in Nigeria

Although The Famished Road offers an insight into a pre-independence epoch, it is also very relevant to post-independence Africa, a revelation of the unsavoury intricacies that permeate the social terrain of a developing country as a result of skewed human relationships and the failed promise of the public sphere. The Abiku myth is used as a political metaphor. The exploits and ordeals of the spirit-child, his vacillation between two worlds (terrestrial and extra-terrestrial), unfold in the socio-political, cultural and moral fabrics of the society. The episodic plot of the novel involves a quest motif, involving three characters (Azaro, Black Tyger/Dad, and Jeremiah, the photographer). One of them (Azaro) is recognized at the apex of the identity-search ladder; the other two are significantly subsumed in the first, but their search is single-mindedly political. The pursuit of a humane and just society in the physical realm is uppermost in their consciousness. Azaro's attempt to navigate life towards self-discovery, as encompassed by the road myth, seems to be rough, tortuous and sinuous:

In the beginning, there was a river. The river became a road, and the road branched out to the whole world. And because the road was once a river, it was always hungry (Okri 1991:1).

The road became my torment, my aimless pilgrimage, and I found myself walking to discover where all the roads lead to, where they end (1991:114).

Through the exploits of Azaro, the reader is able to understand the rigours of existence: 'the unfulfilled longings, the enshrined injustices of the world, the labyrinths of love, the ignorance of parents, the fact of dying' (1991:3). The author describes a political system that has turned into a festering sore. The wide gulf between the rich and the poor is revealed in some people living in clover, while others are condemned to the impecuniousness of the slums, religious perversity, political insincerity on the part of both the Party of the Rich and of the Poor, and other eccentricities. All these impediments discourage Azaro from defining himself permanently within the corporeal reality. In the milieu imaginatively portrayed in this novel, revolutionary nationalist hopes have given way to the disappointments and disillusionment of the 
corrupt post-independence state that Frantz Fanon foretells in Chapter Three of The Wretched of the Earth. The succession of one corrupt regime by another (like the 'coming and going' of the 'Abiku' child) has been a persistent pattern that has defined the politics of almost the entire continent, and one which shows little sign of changing.

Dad (Black Tyger), as a result of his abject poverty and unemployment, resolves to become a boxer to earn a living. His status as a boxer and nonconformist pits him against the Party of the Rich, the governing authorities, his landlord, and at times, Madame Koto - the last two being members of the Party of the Rich. Because of Dad's unyielding opposition to the Party, his landlord hikes his rent, which he bemoans in statements tinged with political rage: 'where am I going to find that kind of money every month, eh? That's how they make you commit murder. Do you see how they force a man to become an armed robber?' (Okri 1991:237). He rebuffs his landlord's attempt to coerce him to vote for the Party of the Rich during an election: 'what right has the landlord to bully us, to tell us who to vote for, eh? Is he God? Even God can't tell us who to vote for. Don't be afraid. We may be poor, but we are no slaves' (1991:203).

In the society portrayed in The Famished Road, politicians are presented as embodiments of greed and corruption. Okri is equally concerned with the indifference which most of the exploited members of the society show toward their conditions. The interrelationship and interdependence required of them to change the status quo is, however, lacking. In spite of the fact that Okri paints a bleak social and political picture of this period of Nigeria's history, he leaves everyone in doubt as to the solution to the problems he has portrayed. This confirms Brenda Cooper's (1998) assertion that Okri's novel is elusive with regard to 'the possibility of change' (89). Okri's ability to recount the impossibility of a stable and acceptable public sphere among the people situates the text within a particular historical period, and this removes it from being a mere magical realist novel and qualifies it as a social realist text. It is when we consider these dissonant and discriminatory human interactions in the novel that the full impact of the social and political decadence really strikes us.

The society depicted in the novel is polarized into the poor, represented by Dad's household and the rich, represented by Dad's landlord and Madame Koto. Okri shows that this society, like most highly stratified societies, is characterized by the exploitation of the poor by the rich. Dad and his neighbours are subject to constant exploitation by the landlord. Even though the roof is leaking, the landlord continues to increase the rent and often threatens to set thugs on them. Only Dad is aware of the social realities and sometimes challenges this domineering figure, while others seem to be less 
concerned. There are no serious and purposeful social interactions geared towards catalyzing a change among the deprived masses. Dad seems to be the only man of conscience struggling to change the society for good. While his family's situation worsens, those of Madame Koto and the landlord improve. Madame Koto in the process is transformed from the kind of woman who helps her needy neighbours. Her metamorphosis is so complete that Azaro says: "she changed completely from the person I used to know, her big frame which seemed to me full of warmth now seemed full of wickedness. I didn't know why she had changed' (1991:251). Madame Koto becomes a stranger to the ghetto dwellers when she comes in contact with the politicians. Through this negative metamorphosis, Okri conjures up, in detail, the abuse of power and national resources by Nigeria's ruling class.

Dad, in his uncontrolled outburst declares: 'some people have too much, and their dogs eat better food, while others suffer and keep quiet until the day they die' (1991:380). His efforts to earn a livelihood afford him an insight into the realities of his society. He awakens to the fact that he, along with other members of his social class, has been condemned to lead a life of hardship and abject poverty from which it is impossible to escape. This situation is even worse on the political front. Political affiliation is deeply polarized in two (The Party of the Rich and The Party of the Poor). Okri uses this polarization to show the difference between the lifestyle of the members of the Party of the Rich and their supporters and those of The Party of the Poor. For members of the Party of the Rich, wealth and power have become the principal pursuit, and the unavoidable consequence of the situation is a total disregard of any moral or social consideration in the drive to satisfy individual desires. This recalls Abubakar Liman's (1999) comment that The Famished Road is 'a way of depicting the life of the poor in Nigeria who are caught between the urge to life, a better life and the difficulties of a system built on injustice and exploitation of man by man' (Liman 1999:70).

For Okri, Nigeria is metaphorically an Abiku child who comes and goes at will. For instance, Dad has a similar notion, as he observes and avers that: 'ours too was an abiku nation, a spirit-child, one that keeps being reborn and after each birth comes blood and betrayal, the child of ours will refuse to stay till we have made propitious sacrifice and displayed our serious intent to bear the weight of a unique destiny' (Okri 1991:494). However, despite all this, Dad is optimistic. He believes that one day:

There will be change ... And when people least expect it; a great transformation is going to take place in the world. Suffering people will know justice and beauty. A wonderful change is coming from far away and people will realize the great meaning of struggle and hope, there will be peace (1991:478). 
The travails of Jeremiah, the photographer, are reflective of the cat-andmouse relationship between the press, writers, and a repressive regime. Jeremiah's ordeals depict the life of many freedom fighters and writers in Africa who are silenced by the government or politicians for attempting to challenge authority. Many of them have been clandestinely murdered, completely silenced by the government, and those who refuse to be silenced are incarcerated. Once, the photographer had to flee into secrecy for a long time after being assailed by the thugs of the Party of the Rich. When his house is attacked, he disappears. He is also sent away from a relative's house when it comes under surveillance. The genesis of his trouble is the taking of pictures of the riot against the Party of the Rich when poisoned milk was being distributed. He takes pictures of the miserable members, especially Black Tyger's landlord who is left reeling in the mire with his torn clothes. He records moments of triumph by the ghetto dwellers and the burnt van of the Party of the Rich. The Party's humiliation gains so much prominence in the papers that thugs seek Jeremiah out for extermination. He is arrested and released after three days, telling tales of torture and brutality he received at the hands of security agents. For displaying pictures at his home of the Rich Party's disgrace, thugs vandalize it. His actions become legendary, but he can no longer continue his trade without molestation. He now makes only nocturnal appearances and becomes a tramp, leading a vagrant life, begging for food. However, despite being hounded, his courage and uncompromising will to expose the ills of the ruling elite become famous. He continues to take pictures of market women fighting with thugs and those of policemen collecting bribes. Such activities are a confirmation of one of the basic tenets of Habermas's public sphere, that is, the public sphere can be animated by opinion-forming associations (voluntary associations, social organizations, churches, sports, clubs, group of concerned citizens, grassroots movements, trade unions and so on) to counter or refashion the messages of authority.

In this work, Okri transmits, analyses, critiques and even transgresses the yearnings of his nation through engagements with myth and historicity and by probing the images and realities of Nigeria's postcolonial experience. From these mytho-cultural experiences and sociological inclinations that have a solid ideological sub-text arise a successful production of a story that narrates the issue of the failed promise of the public sphere in Nigeria. Although the narrative centres on the Abiku myth and is surrounded by almost unending mysteries, the reader is able to obtain a full grasp of political issues in Nigeria. If the continuous disorder and chaos in human life, especially in Nigeria, are anything to go by, there is a need to mythologize experiences and break the 
barriers of conventional realism. This has made Okri's The Famished Road, considering its narrative modes, a 'distinctive combination of the African, and the European, which reflects the collective modes of discourse underlying postmodern parody' (Olatubosun Ogunsanwo 1995:48). Okri uses magic, drawn from the African oral tradition, to make a social statement - all is far from well with Nigeria's public sphere.

Chimamanda Adichie's 'Purple Hibiscus': Allegorizing the Failed Promise of the Public Sphere in Nigeria

Although Purple Hibiscus reads like a mere family saga, it has definite political overtones. It captures the social and political foibles of a neo-colonial African country. It is about tyranny and people's complicity in their oppression; it powerfully evokes the Nigerian political landscape. Through the unhealthy consequences of the filial and domestic conflicts in the story, Adichie calls for an all-inclusive public sphere in Nigerian society. The novel is a political satire that appeals for change in a nation stunted due to the failed promise of the public sphere. An archetype of an average neo-colonial Nigerian ruler, Papa Eugene is intolerant and disallows his family members from the public sphere of his household (allegorically the Nigeria neo-colony). $\mathrm{He}$ is, therefore, depicted as a fanatically religious patriarch, who over-exerts his children academically and religiously debars them from interacting with their neighbourhood. Basil Davidson's (1992) comments on the failure of the public sphere in African countries are relevant to the reading of Adichie's Purple Hibiscus as a social and political allegory:

If the postcolonial nation-state had become a shackle on progress ... the prime reason could appear in little doubt. The state was not liberating and protective of its citizens, no matter what its propaganda claimed: On the contrary, its gross effect was constricting and exploitative, or else had simply failed to operate in any social sense at all (Davidson 1992:23).

This paper argues that meaning is not inherent in Adichie's Purple Hibiscus; rather, it is contextual - a function of the situation within which it is articulated. In reading the work, one must rely on a situated and historical analysis of the specific conditions of the socio-political groups in the story. Thus, Papa Eugene is conceived as a nation's tyrant ruler; his household is a metonym of a nation, and his family signify the dehumanized citizens of the nation. Papa Nnukwu and Aunt Ifeoma are allegorical representations of the radicals and pro-democracy groups in the nation. In Papa Eugene's 'nation', all the factors that are germane to the success of the public sphere are not in existence. This is because the extent of access to the public sphere is not close to universal; the citizens are not free of coercion, and hierarchy is not 
rejected in the milieu, as each member of the family is not given the right to participate on an equal footing (Paul Rutherford 2000).

From the beginning of the story, Papa displays his masculine dominance in his typical African home setting. It is a Palm Sunday, and his son (Jaja) refuses to turn up for the communion. On reaching home, Papa wants to know why Jaja did not attend the communion. Jaja's says that the substances used as the body of Christ give him bad breath, and the priest touches his mouth nauseatingly. Jaja's refusal to attend the communion infuriates Papa who throws his heavy missal at him. This misses the boy but breaks a glass étagère, a precious possession of Mama. Here, it can be seen that the story starts with violence due to the attempt of Papa Eugene to bracket off his wife and children from the family's public sphere. This is first revealed in Jaja's defiance and rebellion: 'Things started to fall apart at home when my brother, Jaja, did not go to communion and Papa flung his heavy missal across the room and broke the figurines on the étagère' (Adichie 2003:4).

Papa Eugene rules his household like a tyrant. The narrator juxtaposes this attitude with that of a tyrant military Head of State. Papa's habitual resort to violence, like an average African despotic ruler, marks the beginning of the breakdown of the family. The family is ruled by the strict authoritarian father, Eugene, who dictates their every move - study schedules, prayer, mass, sleep, church, visitations and the like. He even bans them from spending time with their aged grandfather (his own father) whom he condemns as a heathen. Papa Eugene controls his family through fear and violence, but the violence is never spoken about by the family members who initially keep silent in the face of tyranny. For instance, Kambili and Jaja only communicate with each other through sign language. Papa Eugene's style of 'ruling' his household (his kingdom) is one that offends all known administrative and judicial processes, civilian or military. Things are done brazenly in a manner reminiscent of anarchic times when bestiality is the order of the day. He adopts a monarchical approach to dealing with his family, talking down to them in a manner that makes them felt unworthy of their being human beings.

There is a cat-and-mouse game between the agents of oppressive forces (the ruler of the day and his cohorts) and the resistance forces represented by the tireless press, most especially The Standard. Journalists are always in a privileged position which enables them to mould the opinions of the people by appealing to their sentiments. Unlike other professions where practitioners may die obscure, journalists are exposed to a vista of opportunities on a daily basis, because the community has confidence in them and trusts their judgements. They also have the liberty to address the people and direct their thinking concerning a particular matter. For this reason, journalism becomes 
a yoke for Ade Coker, the versatile editor of The Standard. The reason for his ordeals is not difficult to find. The same privilege enjoyed by him as a journalist is coveted by the dictator; that is, the capacity to control reason, to reinvent and affect other people's thinking. This gives rise to the prevailing tension between the efficient press (represented by Ade Coker) and the totalitarian State. The press is seen to have bravely withstood the tyranny of Nigerian dictators and gone above and beyond their normal remit to uncover news under extremely difficult circumstances and at great personal risk. Of the whole group, Ade Coker is portrayed as the leading force. He may not have suffered losses greater than any other journalist in the country, but he is more resolute and vows to put an end to the despot's reign by whatever means.

Papa Eugene's religious intolerance symbolizes the ugly side of the Nigerian state. The government of the day is depicted as an intolerant one, most especially in its consistent censoring of the press. According to Father Benedict, Papa 'used Standard to speak the truth even though it meant the paper lost advertising' (2003:3). Papa Eugene also asserts, after a coup, that the newspapers in the country 'are all afraid. Writing about how corrupt the civilian government was, as if they think the military will not be corrupt. This country is going down, way down' (2003:26). Kambili, the narrator, also adds that 'in the following weeks, the newspapers we read during family time sounded different, more subdued' (2003:27). Under the military regimes in Nigeria, press freedom was always restricted, often very heavily. The Nigerian Press, that was known to be voluble if not cantankerous, buoyed by a no-holds-barred approach to matters of national interest and with a capacity for advocacy and adversarial writing against those it considered guilty of malfeasance, suddenly lost its salt in the military attempt to subordinate it to the State. This is revealed in the case of Ade Coker, subject to state harassment and eventually killed by a letter bomb. This is a literary inter-text of the actual circumstances surrounding the extra-judicial murder of the popular Editor of Newswatch Magazine, Dele Giwa, in 1986.

Also, in the face of military dictatorship, some journalists become hypocritical, constituting themselves into mere appendages of the military. An example of this is found in the instances where all the other magazines and newspapers in the nation, except The Standard, refuse to condemn the incessant coups in the country, but instead described them merely as a 'Change of Guard' (2003:25). This confirms Rutherford's assertion that large newspapers devoted to profit have turned the press into an agent of manipulation: 'It became the gate through which privileged private interests invaded the public sphere' (Rutherford 2000:185). The veracity of the claim 
of Ali Mazrui (2005:69) that Africa, as a continent, is marked by 'conquerability, docility, malleability and fundamental inferiority' is confirmed in the initial docility of the citizens of the society, here fictionalized in Adichie's Purple Hibiscus.

However, Adichie suggests a way out of the quagmire. To have a space in the public sphere of the society, Mama (Beatrice) and her children (Jaja and Kambili) later reject Papa Eugene's despotic and intolerant acts. They try to correct the anomalies through protests and defiance by Jaja and Kambili, and later through a 'revolution' or 'bloody coup' by Mama. Also, Adichie does not fail to suggest what the situation ought to be in a true democratic setting. This she does through the use of characters like Papa Nnukwu, Jaja and Kambili, and more significantly, Ifeoma, and her children. Despite the fact that Eugene does everything he can to make his father abandon his religion and embrace the Catholic faith, the old man remains resolute:

Papa Nnukwu had told the Umunna how Papa had offered to build him a house, buy him a car, and hire him a driver as long as he converted and threw away the chi in the thatch shrine in his yard ... Papa Nnukwu laughed and said ... he would not throw away his chi; he had already told Papa this many times (Adichie 2003:61).

In spite of his poor living conditions, Papa Nnukwu stands his ground. This is a literary testimony to the unyielding anti-dictatorship temper of a few Nigerians who always remain on the side of the masses and refuse offers by tyrannical rulers. Also significant is the tendentious resistance frequently put up by Jaja. The various episodes of his resistance are suggestive of the hidden cry of the Nigerian masses to find a true expression in a society where the promise of the public sphere has remained perennially unattainable.

On a particular occasion, Kambili suffers menstrual cramps on a Sunday morning, and Mama urges her to take pain killers. As a result of this, Kambili takes her breakfast ten minutes before Mass, which, according to Papa Eugene is a desecration of the Eucharist fast. Papa Eugene is infuriated, without listening to the reason for this desecration. He turns wild:

He unbuckles his belt slowly. It was a heavy belt ... It landed on Jaja first, across his shoulder. Then Mama raised her hands as it landed on her upper arm ... I put the bowl down just as the belt landed on my back (2003:102).

Papa's reason for the indiscriminate flogging of his wife and children is because she watches as the children desecrate the Mass. Papa as a patriarch is well defined - he is cruel, brutal, religiously fanatical, high-handed and oppressive. In another instance, he chops off Jaja's little finger because he misses a question at the Catechism class. Surprisingly, Papa, the looming 
male figure in the story, is a modern and educated man. However, despite his academic sophistication and business acumen, he is bestial in the way he treats his wife and children. He is hard-nosed, and he subjects his family's pain to his whims and caprices. He himself gives the reader the impression that his demeanour is conditioned and dictated by religion.

Women's subjugation and marginalization in the African public sphere come in different ways and shapes. One major way through which this subjectivity of women has continued and thrived is the traditional belief in the society. In other words, societal customs, culture and ways of life help to facilitate norms that subdue women. Papa's hard-nosed stance is sometimes at the detriment of Mama's health. Once, on their way to visit Father Benedict after church, Mama starts to feel ill at ease because of her pregnancy, and she pleads with her husband to allow her stay back in the car. Papa asks twice, 'I asked if you were sure you wanted to stay in the car: Mama looked up, "I'll come with you; it's really not that bad"' (2003:29). She agrees to go with her husband (under duress), not because she is willing or physically fit enough, but because she does not want to displease her husband. Her initial unwillingness to go on the visit is interpreted by Papa as thwarting God's will by putting her selfish desires first. Papa Eugene so much dominates his family that it is only his voice that is loud. He treats other members of the family as mere appendages. Everything, every action and every belief is ranked and scaled according to his standard. It is, therefore, convenient to agree with Lily Mabura's (2008) reading of Adichie's text as a postcolonial gothic novel. This is because the anti-heroic tendencies of Papa Eugene are replicas of the features of a gothic character.

The last dastardly act of Eugene against his wife is breaking a table on her belly, thereby terminating her six-week pregnancy: 'You know that small table where we keep the family bible, nne? Your father broke it on my belly ... My blood finished on that floor even before he took me to St. Agnes. My doctor said there was nothing he could do to save it' (Adichie 2003:47). One gets the impression that Papa Eugene has gone morally berserk, for his actions cannot even be Biblically supported. Through this, and many other similar events in the story, Chimamanda Adichie is trying to discourage the oppressed from over-condoning injustice and oppression before the dehumanizing acts degenerate. Papa Eugene's anti-democratic posture had initially been taken without any counter-reaction. However, this situation transforms Mama into a violent person as revealed in the event that unfolds later. Before her transition into a radical feminist, Mama is depicted as a quintessential traditional woman who does not import Western feminist ideologies into the African worldview. Rather, she establishes a 'safe' point that is favourable to the worldview. She 
also recognizes the nature of her society as being ancient, and that practices and traditions that have existed for years might not be easily changed. With these ideas, she rejects the proposal by her sister-in-law, Ifeoma, on the need to call her marriage off considering the brutalities she has experienced.

Therefore, propelled by her natural pacifist ideology, Mama initially endures her marriage, hoping things will change for the better. For instance, rather than become furious as a result of the unfair treatment meted out by her husband, Mama always remains calm. In a particular instance, when Papa beats her and her children, Mama takes the belt he uses to flog them from him and lays it on the table. However, human patience and resistance to injustice are limited. Patience, in man, alongside the mechanism for its operation and manifestation, is elastic. It detaches upon further stretching; that is, one tends to exhaust one's patience when evolving circumstances are ridiculous, hence unbearable. As a result of this, Papa Eugene's death, through poisoning, is Mama's way of asserting herself and her will. Papa Eugene's tragic end confirms the assertion that oppression will always meet with equal resistance, no matter the place and people, and that good triumphs over evil ultimately, no matter how long evil lasts. The narrator recalls Mama's ingenious way of exterminating the source of her (and her children's) woes:

They have found the poison in your father's body. She sounded as though the poison in Papa's body was something we all had known about, something we had put in there to be found, the way it was done in the books I read where white people hid Easter eggs for their children to find (2003:290).

Mama's way of eradicating Papa Eugene, because of his overbearing attitude, is in consonance with the principle of Radical Feminism - that is the adoption of violence in putting an end to masculine dominance, hence enhancing the liberation of women from the alleged bondage in which men have put them. Through the dissenting relation of Mama to the dominant patriarchal tradition of Africa, Chimamanda Adichie implies that the direction that the feminist campaign is taking currently is a bitter one, and that a violent alternative is not out of the question. This idea is reflected in the later radical temper of Mama, and also revealed in Mama's confession about killing her husband: 'I started putting the poison in his tea before I came to Nsukka. Sisi got it for me; her uncle is a powerful witch doctor' (2003:290). Mama now believes with other radical feminists that violence is the most effective strategy for achieving her freedom.

The violent dimension to the whole situation can be seen as the author's statement that in every woman, no matter how patient, may lie hidden aggression. Here, women assume the mantle of representatives of the masses, 
and that there is a limit to their acquiescence. Silence should not be taken to mean foolishness, laziness, complacency or stupidity.

African women are asserting themselves in different ways. Hopeless situations, at times, need radical solutions. The central character, Kambili, the representative of the author's ideology and beliefs, revolts against the established norms in a society where the promises of the public sphere have consistently failed. Therefore, Adichie envisions a nation where the disempowered womenfolk (the masses) will transgress heterosexual codes in order to free themselves from the shackles of patriarchal suppression. This is an element of resistance against the processes of objectification and heterosexual oppression. Thus, Mama, Kambili and the male-feminist (Jaja) oppose compulsory heterosexuality and gender constructions in order to liberate their true selves and desires. In fact, the enduring brilliance of Adichie's Purple Hibiscus is its ability to oppose hegemony in an effort to challenge the power of established authorities that disempowers the African woman (the marginal subject). Through this effort, Adichie re-empowers the womenfolk (the masses) by giving them a space from which they generate alternative interpretative modes and, in turn, speak out and become an agent of their own history. Towards the end of the story, the trio (Mama, Jaja and Kambili), formerly positioned in the peripheries, now move in a series of resisting movements - translocation and masquerading. Consequently, they are able to protect themselves from being totally decoded. This ultimate resistance serves as a buffer to help in preventing Papa Eugene's continuing acts of appropriation and his egocentric manipulation of the family's (the nation's) public sphere.

\section{Conclusion}

From this study it is clear that, despite all odds against their lives and arts, Nigerian writers refuse to be caged, and constantly intervene in the public sphere of their nation. The study also shows that inscribed in the novels treated here is a prevailing suspicion of the public sphere, evident by the absence of public concern with the sphere. This is an imaginative mimetic representation of the state of fragmentation, state oppression, censorship of Nigerian writers and increasing national exploitation. The political concerns of Nigerian writers, most especially the desire to take on the power of representation of neo-colonial disillusionment in their country and serve as the conscience of the nation, are vividly exposed. But Nigerian rulers have refused to allow the public sphere to become more inclusive. In fact, the actions, inactions, histrionics and dialogues of the characters in these novels reveal that the little space granted the Nigerian masses during the colonial 
period has disappeared due to the unbridled power of the rulers and their fierce pursuit of self interest.

The common motif that is foregrounded in the novels is that, instead of engaging in a free interchange of views, Nigerian neo-colonial rulers, fictionally represented by the President for Life of Kangan (Nigeria) in Anthills of the Savannah, the fanatically religious paterfamilias (Papa Eugene) in Purple Hibiscus and the violent politicians in The Famished Road, repress, judicially murder and jail the governed for daring to express views which are different from those of the rulers. This is symptomatic of the degeneration of the public sphere into violence in the milieu of the texts. In this period of terror, feeble democracy and dictatorship in the country, the Habermasian public sphere is sacrificed to the urgency of political action. This confrontation makes Ikem (in Anthills of the Savannah), Kambili and Jaja (in Purple Hibiscus) and the hopeless masses (in The Famished Road) realize that there is a fundamental contradiction between the utopian space of the public sphere and a tyrannical system of governance in Nigeria that remains largely unchanged since independence.

Another point that merits critical attention is that Achebe, Okri and Adichie present the failed promise of the public sphere as an important element in the Nigerian political society. The novelists, in their respective texts, represent the problem of the potential expansion of the utopian state (the public sphere) to include the political and social concerns of Nigerians; that is, the desire of Nigerian masses to take on the power of representation and to speak for themselves. It is also argued that their novels reveal the refusal of Nigerian rulers to become more inclusive. Ikem (in Anthills of the Savannah), Black Tyger and Photographer (in The Famished Road) and Jaja, Kambili and Mama (in Purple Hibiscus), who think their voices should be heard on public issues, are expelled from the public sphere.

Beyond exhibiting topicality and stylistic innovations, postcolonial Nigerian fiction offers a sustained exploration of the issue of the failed promise of the public sphere, a much-needed theme in current Nigerian literary discourse. It is revealed that, despite all the odds against postcolonial Nigerian fiction writers, there is no sign that an interest in literature of commitment is waning in the country. The reading public of Nigerian fiction has been given a clearer picture of the conditions of the nation's masses than the one offered on the television, radio and the print medium. What unites the three selected novelists, thematically, is a scathing denunciation of the post-independence political situation and the concomitant public disillusionment, a result of the failure of the new governing classes to fulfil the emancipatory promise of independence. Thus, what stands foregrounded in the novels is the cynicism of the masses, 
that is, the disgust felt with the mess that their elected representatives and the military rulers have made of their country. What is highlighted and critically interrogated in the texts is the attempt of the rulers to erode the legitimacy of a defensible core of rights (public sphere). In this sense, we can say that postcolonial Nigerian fiction offers imaginative case studies of violated human rights in the nation. The formal structure of the novels also revolves around dissonance between rulers and the ruled. The texts give an imaginative representation of the total inadequacy of the public sphere, and offer a vision of human vulnerability and dependency that presents a much-needed corrective to the excessively inflated present-day aspirations for human rights.

The survival of the philosophy of harmony and integration among the diverse people of Nigeria, that is, the concept and significance of the collective will, is under great threat in the cosmos of each of the novels. Due to the refusal of the rulers to allow the masses to be active participants in the nation's public sphere, the expected collective will is jettisoned in favour of the European cosmic will. Collective will is a force that operates in a communalistic society like Nigeria, where the emphasis for group survival overrides that of the individual. The primacy of place is supposed to be given to the group rather than the individual, because it is understood that the part exists within the whole (Zulu Sofola 1988). Therefore, Sam, the Head of State of Kangan, the corrupt politicians and their cohorts, and Papa Eugene all ignore the fact that, in Africa, the power and strength of the individual exist in the strength of the collective will of the group (see for example Kwame Nkrumah's Conscienticism, 1964). Each of the fictional despots falls from grace to grass because of their hubris; that is, appropriation of the power of the collective will to themselves.

Clearly, these novelists are suggesting that an inclusive public sphere and the freedom of the press and of creative writers are the cornerstone of democracy. Nigerian writers have a right to serve as the conscience of their society. Nigerian writers should be able to enjoy the hard-won freedom of imaginatively reflecting and refracting the foibles of their rulers and the ruled. Neo-colonial Nigerian rulers should see the writers as partners in progress, rather than as illegitimate interlocutors in the nation's public sphere.

Given all that has been said about the problem of the failed promise of the public sphere in Nigeria, as narrated in the selected prose texts, it is suggested that there should be a harmonious blend of all the segments of the citizens of the nation (poor or rich, young or old, female or male, disabled or nondisabled, employee or employer, ruler or the ruled, literate or illiterate, and the like) to enable each citizen fulfil his or her destiny and achieve the inalienable right of self-realization and actualization without the destruction of the whole. 
It is the total rejection of this philosophy that leads the rulers in the texts to their tragic ends. They use the power vested in them to destroy other lives and are, therefore, evil agents who must be punished and expunged. One didactic message which is a motif in postcolonial Nigerian fiction is that lawabiding citizens of the country must be allowed to take their rightful place in the order of the universe and the political set-up of the nation, and they must seek to maintain the cosmic equilibrium of the nation. This viewpoint conscientizes the masses of the societies portrayed in the selected novels to engage in real and latent revolts. They are ready to drive basic issues home and effect a change. This temper may offer an antidote for leading our groping nation from the woods of confusion, despotism, totalitarianism and anarchy.

\section{References}

Achebe, C., 1984, The Trouble with Nigeria, London: Heinemann.

Achebe, C., 1987, Anthills of the Savannah, London: Heinemann.

Adichie, C., 2003, Purple Hibiscus, Lagos: Farafina.

Cooper, B., 1988, Magical Realism in West African Fiction: Seeing with a Third Eye, New York: Routledge.

Davidson, B., 1992, The Black Man's Burden: Africa and the Course of the Nation State, New York: Times Books.

Fanon, F., 1968, The Wretched of the Earth, Translated by Constance Farrington, New York: Grove Press.

Frazer, N., 1992, 'Rethinking the Public Sphere: A Contribution to the Critique of Actually Existing Democracy', in Habermas and the Public Sphere, Craig Calhoun, ed., Cambridge, MA: MIT Press.

Frye, N., 1944-45, 'The Nature of Satire', University of Toronto Quarterly. XIV, 7980.

Glover, B., 2004, 'The Public Sphere and Formal Nostalgia, 1709-1785', PhD Dissertation, University of Virginia.

Habermas, J., 1991, The Structural Transformation of the Public Sphere: An Inquiry into a Category of Bourgeois Society, Translated by Thomas Burger and Frederick Lawrence, Cambridge, MA: MIT Press.

JanMohamed, A., 1983, Manichean Aesthetics, Amherst: University of Massachusetts Press.

Liman, A., 1977, 'Postcolonial Discourse: The Case of Ben Okri's Famished Road', Currents in African Literature and the English Language, Volume 1, Number $1,63-79$.

Mabura, L., 2008, 'Breaking Gods: An African Postcolonial Gothic Reading of Chimamanda Ngozi Adichie's Purple Hibiscus and Halfa Yellow Sun', Research in African Literatures, 39 (1), Spring, 203-222.

Mazrui, A., 2005, 'The Re-invention of Africa: Edward Said, Y.Y. Mudimbe and Beyond', Research in African Literatures, 36 (3), Fall, 68-82. 
Ngara, E., 1990, 'Achebe as Artist: The Place and Significance of Anthills of the Savannah', Kunapipi, 12 (2), 113-129.

Nkrumah, K., 1964, Conscienticism, London: Heinemann.

Ogunsanwo, O., 1995, 'Intertextuality and Post-Colonial Literature in Ben Okri's The Famished Road', Research in African Literatures, 26 (1), 40-52.

Ojinma, U., 1991, Chinua Achebe: New Perspectives, Ibadan: Spectrum.

Okri, B., 1991, The Famished Road, London: Jonathan Cape.

Osundare, N., 2007, The Writer as a Righter, Ibadan: Hope Publications.

Rutherford, P., 2000, Endless Propaganda: The Advertising of Public Goods, Toronto: University of Toronto Press.

Sofola, Z., 1988, 'African Society and the Concept of Freedom', Okike, 27/28, 74-87. Szeman, I., 1998, 'On National Cultures: Literary Politics in Canada, the Caribbean and Nigeria, 1952-1970’, Doctoral Thesis, Duke University.

Williams, A., 1996, 'Literature in the Time of Tyranny: African Writers and the Crisis of Governance', Third World Quarterly, 17 (2), 349-362.

Young, C., 2004, 'The End of the Post-colonial State in Africa? Reflections on Changing African Political Dynamics', African Affairs, 103, 23-49. 
